JAMP: Jurnal Adminitrasi dan Manajemen Pendidikan

Volume 3 Nomor 1 Maret 2020, Hal : 90-101

Tersedia Online di http://journal2.um.ac.id/index.php/jamp/

ISSN 2615-8574 (online)

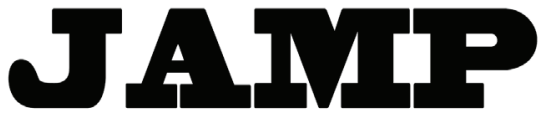

JURNAL ADMINISTRASI DAN MANAJEMEN PENDIDIKAN

\title{
ANALISIS KEPUASAN PESERTA DIDIK TERHADAP LAYANAN EVALUASI HASIL BELAJAR ONLINE
}

\author{
Dwi Ayu Kusumawardhani \\ Burhanuddin \\ Universitas Negeri Malang, Jalan Semarang 5 Malang 65145 \\ e-mail: dwiayukw14@gmail.com
}

\begin{abstract}
This study was conducted to describe: (1) the level of learners' expectations about Online Learning Outcomes Evaluation Services at SMK Negeri 3 Malang; (2) the level of reality according to students' perceptions about Online Learning Outcomes Evaluation Services at SMK Negeri 3 Malang; (3) the difference between students' expectations and perceptions about Online Learning Outcomes Evaluation Services at SMK Negeri 3 Malang. This research used a quantitative approach with a comparative research design. The instrument used in this study was a closed questionnaire. Data analysis used descriptive technique and One Way Anova. Based on the results of the data analysis conclusions are drawen as follow: (1) the level of students' expectations about Online Learning Outcomes Evaluation Services in SMK Negeri 3 Malang is in quite satisfied category; (2) in reality Online Learning Outcomes Evaluation Services are of reganded of quite satisfied; (3) there is no significant difference between students' expectations and perceptions about Online Learning Outcomes Evaluation Services at State Vocational School 3 Malang.
\end{abstract}

Keywords: student satisfaction; Online learning outcomes evaluation services

\begin{abstract}
Abstak: Penelitian ini dilakukan untuk menggambarkan: (1) tingkat harapan peserta didik tentang Layanan Evaluasi Hasil Belajar Online di SMK Negeri 3 Malang; (2) tingkat realitas menurut persepsi siswa tentang Layanan Evaluasi Hasil Pembelajaran Online di SMK Negeri 3 Malang; (3) perbedaan antara harapan dan persepsi siswa tentang Layanan Evaluasi Hasil Belajar Online di SMK Negeri 3 Malang. Penelitian ini menggunakan pendekatan kuantitatif dengan desain penelitian komparatif. Instrumen yang digunakan dalam penelitian ini adalah kuesioner tertutup. Analisis data menggunakan teknik deskriptif dan One Way Anova. Berdasarkan hasil analisis data dapat ditarik kesimpulan sebagai berikut: (1) tingkat harapan siswa tentang Layanan Evaluasi Hasil Belajar Online di SMK Negeri 3 Malang berada dalam kategori cukup puas; (2) pada kenyataannya Layanan Evaluasi Hasil Belajar Online berada dalam kategori cukup puas; (3) tidak ada perbedaan yang signifikan antara harapan dan persepsi siswa tentang Layanan Evaluasi Hasil Belajar Online di Sekolah Menengah Kejuruan 3 Malang.
\end{abstract}

Kata kunci: kepuasan peserta didik; layanan evaluasi hasil belajar Online

Kebutuhan individu dari tahun ke tahun selalu mengalami peningkatan yang signifikan dikarenakan kebutuhan terhadap sesuatu selalu berubah-ubah mengikuti perkembangan zaman yang semakin pesat. Berkembangnya Ilmu Pengetahuan dan Teknologi (IPTEK) juga akan berpengaruh pada teknologi yang digunakan untuk mempermudah kegiatan yang dilakukan sehari-hari. Kemajuan ilmu pengetahuan dan teknologi berdampak positif terhadap berkembangan budaya sehingga daya saing manusia juga ditentukan penguasaan teknologi. Oleh karena itu, untuk menuju masyarakat yang berdaya saing tinggi, harus disiapkan sistem pendidikan yang mampu memberi bekal pengetahuan dan pemanfaatan teknologi bagi outputnya. Hasil yang di dapat dari adanya pelayanan yang diberikan oleh sekolah dapat dilihat dari puas tidaknya peserta didik tersebut, hal ini dapat diartikan bahwa sekolah sebagai lembaga pendidikan 
harus terus berusaha memberikan layanan yang berkualitas kepada pelanggannya. Peningkatan layanan jika terus diupayakan akan menghasilkan kepuasan tersendiri bagi peserta didik.

Kepuasan peserta didik dapat dikatakan sebagai kepuasan pelanggan pengguna jasa pelayanan. Kepuasan pelanggan adalah perasaan senang atau tidak senang dari seseorang pengguna jasa layanan, sedangkan menurut Hasibuan (2012:1) menyatakan bahwa "kepuasan dapat diartikan sebgai perasaan puas, rasa senang, dan kelegaan seseorang dikarenakan mengkonsumsi suatu produk atau jasa untuk mendapatkan pelayanan suatu jasa". Menurut Liana (2016: 39) kepuasan pelanggan merupakan salah satu faktor penentu keberhasilan dalam memberikan layanan. Kepuasan pelanggan dapat dijadikan tolok ukur oleh sekolah apakah sudah berhasil atau belum dalam memberikan pelayanan kepada peserta didik.

Pelanggan dalam dunia pendidikan menurut Sallis (2010:71) "pelanggan lembaga pendidikan secara internal adalah guru dan staf yang ada di sekolah. Sedangkan secara eksternal pelanggan lembaga pendidikan adalah orang tua siswa dan masyarakat. Siswa merupakan pelanggan utama. Sejalan dengan itu, Rahma \& Hartoyo (2010:2) mengemukakan bahwa "peserta didik dan orangtua peserta didik disebut sebagai pengguna jasa pendidikan atau pelanggan". Kepuasan yang didapatkan oleh pelanggan atau pengguna jasa dapat diukur dari kualitas layanan yang diberikan oleh sekolah.

Kualitas dikatakan baik dapat dilihat dari produk yang diberikan sekolah mampu memberikan kepuasan terhadap pelanggan atau tidak. Menurut Wijaya (2011:11) kualitas merupakan "sesuatu yang diputuskan oleh pelanggan". Artinya kualitas didasarkan pada pengalaman aktual pelanggan atau konsumen terhadap produk atau jasa yang diukur berdasarkan persyaratan tertentu". Penjaminan mutu atau kualitas dapat dilakukan dengan sekolah berpedoman pada Undang-Undang Nomor 20 Tahun 2003 tentang Sistem Pendidikan Nasional dan Peraturan Pemerintah Nomor 19 Tahun 2005 tentang Standar Nasional Pendidikan yang menyatakan bahwa penjaminan kualitas atau mutu adalah wajib bagi internal maupun eksternal.

Sekolah mengemban tugas penting untuk memberikan pelayanan yang bermutu dan baik kepada peserta didik sebagai pelangan atau pengguna jasa. Peserta didik sebagai pelanggan atau pengguna jasa tentu mengharapkan pelayanan dari sekolah yang bermutu atau berkualitas seperti ruang tempat pelaksanaan Evaluasi Hasil Belajar Online yang luas dan bersih, yang tenang dan jauh dari kebisingan, sehingga peserta didik dapat melaksanakan Evaluasi Hasil Belajar dengan maksimal. Harapan peserta didik itulah yang diyakini memiliki peranan yang besar dalam menentukan kualitas dari pelayanan yang diberikan oleh sekolah. Pelaksanaan Evaluasi Hasil Belajar Online sudah diterapkan dari beberapa tahun terakhir pada Ujian Nasional (UN) di Indonesia dengan menggunakan komputer dan juga akses internet, yang membedakan dari Evaluasi Hasil Belajar Online dengan tes tulis terletak pada butir tes baik itu butir soal maupun lembar jawaban yang tidak lagi tertulis di sebuah kertas melainkan sudah menggunakan komputer. Evaluasi Ujian Online di Indonesia telah diatur oleh Badan Standar Nasional Pendidikan (BSNP) Nomor 0032/P/BSNP/III/2015 tentang Pelaksanaan Ujian Nasional Berbasis Komputer/Computer Based Test (UNBK)/(CBT) Tahun Pelajaran 2014/2015.

Kota Malang sendiri telah menerapkan Evaluasi Hasil Belajar Online sejak Tahun 2015 yang digunakan pada Ujian Nasional Tingkat SMA/SMK Negeri. Berdasarkan informasi dari hasil studi penelitian, dikatakan bahwa salah satu dari pelaksana pengguna Evaluasi Hasil Belajar Online adalah SMK Negeri 3 Malang. SMK Negeri 3 Malang merupakan sekolah percobaan pertama di Kota Malang yang ditugaskan untuk melakukan uji coba ujian menggunakan CBT atau komputer pada Tahun 2014. Evaluasi yang dilaksanakan secara Online di SMK Negeri 3 Malang adalah Ujian Tengah Semester (UTS), Ujian Akhir Semester, Ujian Tryout dan Ujian Akhir Sekolah (UAS), sedangkan Ujian Akhir Nasional (UAN) dilaksanakan secara Online sesuai dengan Peraturan Pemerintah. Evaluasi Hasil Belajar Online line dilaksanakan pada semua jurusan di SMK Negeri 3 Malang.

Pelaksanaan evaluasi hasil belajar Online akan diperhatikan sejauh manakah layanan ini dapat memberikan kepuasan bagi peserta didik sebagai pengguna langsung dari layanan ini. Penelitian terdahulu mengenai kepuasan peserta didik terhadap layanan evaluasi hasil belajar Online pernah dilakukan oleh beberapa peneliti, diantaranya dilakukan oleh Sholikhah (2015), Ashary (2018), dan Rizki (2017). Penelitian oleh Sholikhah (2015) dilaksanakan di SMK Negeri 5 Malang dengan hasil 
penelitian menunjukkan bahwa persentase tertinggi ada pada sub variabel sistem ujian Online dengan nilai sebesar $93,75 \%$ kategori sangat setuju, sedangkan kategori sangat setuju terendah pada sub variabel kesiapan mengikuti ujian Online yaitu sebesar 62,5\%. Tanggapan peserta didik di SMK Negeri 5 Malang cenderung termasuk dalam klasifikasi tinggi. Sedangkan penelitian oleh Ashary (2018) dilaksanakan di SMK Muhamadiyah 5 Kepanjen dengan hasil penelitian menyatakan bahwa penggunaan media evaluasi pembelajaran berbasis komputer menggunakan aplikasi wondershare quiz creator dapat meningkatkan hasil belajar siswa pada mata pelajaran akuntansi yang berada pada kategori tinggi dibandingkan menggunakan media evaluasi pembelajaran paperbased yang berada pada kategori rendah. Dan untuk penelitian Rizki (2017) dilaksanakan di Fakultas ilmu Pendidikan Universitas negeri Malang (FIP UM) menunjukkan kondisi kualitas layanan masuk dalam kualifikasi sedangan dan berada pada rentang nilai 125-154 dengan skor rata-rata 140,34. Kepuasan mahasiswa FIP UM masuk dalam kualifikasi sedang dan berada pada rentang nilai 87- 113 dengan skor rata-rata 99,42. Intensitas pemanfaatan layanan peminjaman mempunyai rata-rata 11,76 berada pada kualifiasi sedangn, intensitas pemanfaatan layanan serial mempunyai rata-rata 9,03 berada pada kualifikasi sedang, intensitas pemanfaatan layanan Online mempunyai rata-rata 15,48 , berada pada kualifikasi sedang, intensitas pemanfaatan layanan referensi mempunyai rata-rata 9,57 berada pada kualifikasi sedang.

Berdasarkan uraian di atas, maka yang menjadi tujuan penelitian ini adalah (1) Mendeskripsikan tingkat ekspektasi peserta didik tentang Layanan Evaluasi Hasil Belajar Online di SMK Negeri 3 Malang, (2) Mendeskripsikan tingkat kenyataan menurut persepsi peserta didik tentang Layanan Evaluasi Hasil Belajar Online di SMK Negeri 3 Malang, (3) Mendeskripsikan perbedaan ekspektasi dan persepsi peserta didik tentang Layanan Evaluasi Hasil Belajar Online di SMK Negeri 3 Malang.

\section{METODE}

Penelitian ini merupakan penelitian deskriptif dengan desain penelitian komparatif yang bertujuan untuk mendeskripsikan atau menggambarkan fenomena yang ada baik yang bersifat alamiah maupun rekayasa manusia. Penelitian ini bertujuan untuk menggambarkan fakta yang terdapat dilapangan mengenai kepuasan peserta didik terhadap Layanan Evaluasi Hasil Belajar Online. Lokasi penelitian ini bertempat di SMK Negeri 3 Malang. SMK Negeri 3 Malang merupakan salah sekolah yang dijadikan contoh dalam pelaksanaan Evaluasi Hasil Belajar Online sejak tahun ajaran 2014/2015. SMKN Negeri 3 Malang memiliki 5 jurusan yakni perhotelan, tata kecantikan, tata boga, tata busana, serta teknik komputer dan jaringan. SMK Negeri 3 Malang terletak di Jalan Surabaya No. 1, Klojen Kota Malang.

Populasi yang digunakan dalam peneliltian ini adalah peserta didik kelas XI dan kelas XII yang menggunakan Layanan Evaluasi Hasil Belajar Online di SMK Negeri 3 Malang. Jumlah peserta didik pengguna Layanan Evaluasi Hasil Belajar Online di SMK Negeri 3 Malang berdasarkan data yang di dapatkan dari nasumber yakni Pegawai Kesiswaan SMK Negeri 3 Malang adalah 855 peserta didik. Pengambilan sampel dalam penelitian ini ditentukan berdasarkan penentuan jumlah sampel dari rumus Slovin (dalam Setyadin, 2005:20), perhitungan tersebut menunjukkan bahwa sampel pada penelitian ini ada sebanyak 272 responden yang keseluruhannya adalah peserta didik kelas XI dan kelas XII pengguna Layanan Evaluasi Hasil Belajar Online di SMK Negeri 3 Malang. Peneliti menggunakan batas kesalahan yang ditolerir sebesar 5\%.

Jenis instrumen dalam penelitian ini menggunakan angket/kuisioner tertutup. Angket/ kuisioner merupakan teknik pengumpulan data dengan menyerahkan atau mengirimkan daftar pertanyaan untuk diisi oleh responden. Penelitian ini menggunakan pengukuran Skala Likert dengan skala 1-5 yang telah dimodifikasi. Sebelum digunakan untuk penelitian instrumen ini harus terlebih dahulu di uji coba dengan tujuan untuk mengetahui seberapa valid dan reliabilitas dari instrumen penelitian yang akan digunakan untuk penelitian. Uji validitas dalam penelitian ini digunakan untuk mengetahui tingkat kelayakan dari instrumen yang telah dibuat. Uji validitas penelitian ini menggunakan IBM SPSS Statistic 23 dengan metode analisis faktor. Analisis faktor yang digunakan dalam penelitian ini adalah Explanatory Factor Analysis dengan dimention reduction pada IBM SPSS Statistic 23. 
Teknik analisis data yang digunakan dalam penelitian ini adalah teknik analisis deskriptif dengan menggunakan formula stanfive; Analisis Importance and Performance Matrix digambarkan dalam bentuk diagram kartesius, yaitu suatu bangun yang terbagi atas empat kuadran dengan dibatasi oleh dua garis yang berpotongan tegak lurus pada titik-titik (X, Y) dimana X adalah skor rata-rata dari penilaian kinerja atau jasa yang diraasakan dan $\mathrm{Y}$ adalah skor rata-rata penilaian kepentingan yang diharapkan mempengaruhi kepuasan peserta didik; Penelitian ini juga di analisis dengan menggunakan One Way Anova karena variabel dependen dan independennya berjumlah satu. Taraf yang digunakan dalam anova adalah 0,05. Uji normalitas dapat terlaksana apabila skor pada setiap item dalam model mengikuti distribusi normal. Uji normalitas data dilakukan dengan uji test normalitas Kolmogorov Smirnov dengan dibantu komputer menggunakan program IBM SPSS Statistics 23.

\section{HASIL}

Berdasarkan hasil analisis deskriptif memperlihatkan distribusi frekuensi tingkat ekspektasi peserta didik terhadap layanan evaluasi hasil belajar interval $>178,12$ terdapat sebanyak 8 responden dengan 2,9\% masuk dalam ketegori sangat baik; interval 170,38-178,12 terdapat sebanyak 80 responden dengan $29,4 \%$ masuk dalam kategori baik; interval 162,64-170,38 terdapat sebanyak 103 responden dengan $37,9 \%$ masuk dalam kategori cukup baik; interval 154,90-162,64 terdapat sebanyak 66 responden dengan 24,3\% masuk dalam kategori kurang baik; interval $<154,90$ terdapat sebanyak 21 responden dengan 5,5\% masuk dalam kategori tidak baik. Dillihat dari distribusi frekuensi tingkat ekspektasi tersebut diperoleh hasil bahwa tingkat ekspektasi peserta didik dalam kategori cukup baik.

Tabel 1. Analisis Deskriptif Tingkat Ekspektasi Peserta Didik tentang Layanan Evaluasi Hasil Belajar Online

\begin{tabular}{ccccc}
\hline No & Interval & F & $\%$ & Kategori \\
\hline 1 & $>178,12$ & 8 & 2,9 & Sangat Baik \\
2 & $170,38-178,12$ & 80 & 29,4 & Baik \\
3 & $162,64-170,38$ & 103 & 37,9 & Cukup Baik \\
4 & $154,90-162,64$ & 66 & 24,3 & Kurang Baik \\
5 & $<154,90$ & 21 & 5,5 & Tidak Baik \\
& Jumlah & 272 & 100 & \\
\hline
\end{tabular}

Distribusi frekuensi tingkat kenyataan peserta didik terhadap layanan evaluasi hasil belajar Online interval > 145,52 terdapat sebanyak 19 responden dengan 7,0 \% masuk dalam ketegori sangat baik; interval 137,47-145,52 terdapat sebanyak 59 responden dengan $21,7 \%$ masuk dalam kategori baik; interval 129,41-137,47 terdapat sebanyak 118 responden dengan 43,4\% masuk dalam kategori cukup baik; interval 121,36-129,41 terdapat sebanyak 63 responden dengan $23,2 \%$ masuk dalam kategori kurang baik; interval $<121,36$ terdapat sebanyak 13 responden dengan 4,8 \% masuk dalam kategori tidak baik, diperoleh hasil tingkat kenyataan dalam kategori cukup baik.

Tabel 2. Analisis Deskriptif Tingkat Kenyataan menurut Persepsi Peserta Didik tentang Layanan Evaluasi Hasil Belajar Online

\begin{tabular}{ccccc}
\hline No & Interval & F & $\%$ & Kategori \\
\hline 1 & $>145,52$ & 19 & 7,0 & Sangat Baik \\
2 & $137,47-145,52$ & 59 & 21,7 & Baik \\
3 & $129,41-137,47$ & 118 & 43,4 & Cukup Baik \\
4 & $121,36-129,41$ & 63 & 23,2 & Kurang Baik \\
5 & $<121,36$ & 13 & 4,8 & Tidak Baik \\
& Jumlah & 272 & 100 & \\
\hline
\end{tabular}


Berdasarkan hasil Explanatory Factor Analysis (EFA), maka dapat disimpulkan skala pengukuran variabel kepuasan peserta didik terhadap layanan evaluasi hasil belajar Online menghasilkan 5 sub skala pengukuran yakni terdiri dari skala bukti fisik item 1,2,3,4,5,6,7,8,9 dengan Cronbach's Alpha harapan sebesar 0,741 sedangkan Cronbach's Alpha kenyataan sebesar 0,715; skala keandalan item 10,11,12,13,14,15 dengan Cronbach's Alpha harapan sebesar 0,697 sedangkan Cronbach's Alpha kenyataan sebesar 0.652; skala daya tanggap item 16,17,18,19,20,21 dengan Cronbach's Alpha harapan sebesar 0,749 sedangkan Cronbach's Alpha kenyataan sebesar 0,601; skala jaminan item 22,23,24,25,26,27 dengan Cronbach's Alpha harapan sebesar 0,673 sedangkan Cronbach's Alpha kenyataan sebesar 0,578; dan skala empati item 28,29,30,31,32,33,34,35,36 dengan Cronbach's Alpha harapan sebesar 0,798 sedangkan Cronbach's Alpha kenyataan sebesar 0,659.

Berdasarkan hasil One Way ANOVA variabel tingkat ekspektasi peserta didik, dapat disimpulkan bahwa pada tabel deskriptif menunjukkan ada perbedaan harapan dari setiap jurusan dengan masingmasing rincian sebagai berikut: Rata-rata harapan jurusan TKJ sebesar 164,74, rata-rata harapan jurusan PH sebesar 167,15, rata-rata harapan jurusan TBG sebesar 166,98, rata-rata harapan jurusan KC sebesar 166,37, rata-rata harapan jurusan TBS sebesar 166,51. Maka dengan demikian secara deskriptif dapat disimpulkan bahwa rata-rata harapan tertinggi adalah jurusan PH yakni sebesar 167,15. Pada tabel homogenitas diperoleh nilai signifikansi (Sig.) sebesar 0,000. Karena nilai signifikansi $0,000<0,05$, maka dapat disimpulkan bahwa varian dari kelima jurusan yang dibandingkan adalah tidak homogen. Pada tabel One Way Anova di atas, diketahui bahwa nilai signifikan sebesar 0,557 > 0,05. Sehingga dapat disimpulkan bahwa rata-rata harapan dari kelima jurusan tersebut "sama" secara signifikan.

Tabel 3. One Way Anova Variabel Tingkat Ekspektasi Peserta Didik terhadap Layanan Evaluasi Hasil Belajar Online

HARAPAN

Descriptives

\begin{tabular}{|c|c|c|c|c|c|c|c|c|}
\hline & \multirow[b]{2}{*}{$\mathbf{N}$} & \multirow[b]{2}{*}{ Mean } & \multirow[b]{2}{*}{$\begin{array}{c}\text { Std. } \\
\text { Deviation }\end{array}$} & \multirow[b]{2}{*}{$\begin{array}{l}\text { Std. } \\
\text { Error }\end{array}$} & \multicolumn{2}{|c|}{$\begin{array}{l}95 \% \text { Confidence } \\
\text { Interval for Mean }\end{array}$} & \multirow[b]{2}{*}{ Minimum } & \multirow[b]{2}{*}{ Maximum } \\
\hline & & & & & $\begin{array}{l}\text { Lower } \\
\text { Bound }\end{array}$ & $\begin{array}{l}\text { Upper } \\
\text { Bound }\end{array}$ & & \\
\hline TKJ & 43 & 164,74 & 12,006 & 1,831 & 161,05 & 168,44 & 131 & 180 \\
\hline PH & 54 & 167,15 & 6,663 & ,907 & 165,33 & 168,97 & 152 & 179 \\
\hline TBG & 66 & 166,98 & 6,372 & ,784 & 165,42 & 168,55 & 150 & 178 \\
\hline $\mathrm{KC}$ & 44 & 166,95 & 7,317 & 1,103 & 164,73 & 169,18 & 149 & 179 \\
\hline TBS & 65 & 166,37 & 6,487 &, 805 & 164,76 & 167,98 & 150 & 179 \\
\hline Total & 272 & 166,51 & 7,737 & ,469 & 165,59 & 167,43 & 131 & 180 \\
\hline
\end{tabular}

Test of Homogeneity of Variances

HARAPAN

\begin{tabular}{cccc}
\hline Levene Statistic & df1 & df2 & Sig. \\
\hline 10,099 & 4 & 267 &, 000 \\
\hline
\end{tabular}

ANOVA

HARAPAN

\begin{tabular}{cccccc}
\hline & Sum of Squares & df & Mean Square & F & Sig. \\
\hline Between Groups & 180,934 & 4 & 45,233 &, 753 &, 557 \\
Within Groups & 16041,033 & 267 & 60,079 & & \\
Total & 16221,967 & 271 & & & \\
\hline
\end{tabular}


Berdasarkan hasil One Way ANOVA variabel tingkat kenyataan peserta didik, dapat disimpulkan bahwa pada tabel deskriptif menunjukkan ada perbedaan harapan dari setiap jurusan dengan masingmasing rincian sebagai berikut: Rata-rata kenyataan jurusan TKJ sebesar 132,65, rata-rata kenyataan jurusan PH sebesar 133,07, rata-rata kenyataan jurusan TBG sebesar 132,77, rata-rata kenyataan jurusan KC sebesar 133,59, rata-rata kenyataan jurusan TBS sebesar 134,86. Maka dengan demikian secara deskriptif dapat disimpulkan bahwa rata-rata kenyataan tertinggi adalah jurusan TBS sebesar 134,86. Pada tabel homogenitas diperoleh nilai signifikansi (Sig.) sebesar 0,068. Karena nilai signifikansi 0,068 $>0,05$, maka dapat disimpulkan bahwa varian dari kelima jurusan yang dibandingkan adalah homogen. Pada tabel One Way Anova di tas, diketahui bahwa nilai signifikan sebesar 0,558 >0,05. Sehingga dapat disimpulkan bahwa rata-rata harapan dari kelima jurusan tersebut "sama" secara signifikan.

Tabel 4. One Way Anova Variabel Tingkat Kenyataan Peserta Didik terhadap Layanan Evaluasi Hasil Belajar Online

KENYATAAN

\section{Descriptives}

\begin{tabular}{|c|c|c|c|c|c|c|c|c|}
\hline & \multirow[b]{2}{*}{$\mathbf{N}$} & \multirow[b]{2}{*}{ Mean } & \multirow[b]{2}{*}{$\begin{array}{c}\text { Std. } \\
\text { Deviation }\end{array}$} & \multirow[b]{2}{*}{$\begin{array}{l}\text { Std. } \\
\text { Error }\end{array}$} & \multicolumn{2}{|c|}{$\begin{array}{l}\text { 95\% Confidence } \\
\text { Interval for Mean }\end{array}$} & \multirow[b]{2}{*}{ Minimum } & \multirow[b]{2}{*}{ Maximum } \\
\hline & & & & & $\begin{array}{l}\text { Lower } \\
\text { Bound }\end{array}$ & $\begin{array}{l}\text { Upper } \\
\text { Bound }\end{array}$ & & \\
\hline TKJ & 43 & 132,65 & 9,892 & 1,509 & 129,61 & 135,70 & 107 & 156 \\
\hline PH & 54 & 133,07 & 9,322 & 1,269 & 130,53 & 135,62 & 106 & 150 \\
\hline TBG & 66 & 132,77 & 7,312 & ,900 & 130,98 & 134,57 & 114 & 155 \\
\hline KC & 44 & 133,59 & 7,378 & 1,112 & 131,35 & 135,83 & 105 & 149 \\
\hline TBS & 65 & 134,86 & 6,668 &, 827 & 133,21 & 136,51 & 119 & 147 \\
\hline Total & 272 & 133,44 & 8,053 & ,488 & 132,48 & 134,41 & 105 & 156 \\
\hline
\end{tabular}

Test of Homogeneity of Variances

KENYATAAN

\begin{tabular}{cccc}
\hline Levene Statistic & df1 & df2 & Sig. \\
\hline 2,217 & 4 & 267 &, 068 \\
\hline
\end{tabular}

ANOVA

KENYATAAN

\begin{tabular}{cccccc}
\hline & Sum of Squares & df & Mean Square & F & Sig. \\
\hline Between Groups & $\mathbf{1 9 5 , 7 2 1}$ & 4 & $\mathbf{4 8 , 9 3 0}$ & $\mathbf{7 5 2}$ & $\mathbf{5 5 8}$ \\
Within Groups & $\mathbf{1 7 3 7 7 , 4 5 2}$ & $\mathbf{2 6 7}$ & $\mathbf{6 5 , 0 8 4}$ & & \\
Total & $\mathbf{1 7 5 7 3 , 1 7 3}$ & $\mathbf{2 7 1}$ & & & \\
\hline
\end{tabular}

Analisis Importance and Performance Matrix dilakukan dengan menghitung nilai mean atau nilai rata-rata setiap item pernyataan dari variabel Importance maupun Performance. Apabila setiap layanan yang dianggap penting oleh peserta didik namun pada pelaksanaannya kurang baik, maka diperlukan perhatian yang lebih dari pihak sekolah, sebaliknya apabila setiap layanan yang tidak dianggap penting oleh peserta didik namun pada pelaksanaannya mendapat perhatian lebih dari sekolah, maka perlu juga diperhatikan. Dengan adanya gap yang besar dari Importance maupun Performance dapat digunakan sebagai gambaran bagi pihak sekolah untuk memprioritaskan perbaikan item layanan yang memerlukan tindakan perbaikan. 
Tabel 5. Perhitungan GAP Importance and Performance Matrix

\begin{tabular}{|c|c|c|c|c|}
\hline No. & Keterangan & $\begin{array}{c}\text { Mean } \\
\text { Harapan }\end{array}$ & $\begin{array}{c}\text { Mean } \\
\text { Kenyataan }\end{array}$ & GAP \\
\hline 1 & Penggunaan komputer saat evaluasi hasil belajar & 4,59 & 3,67 & 0,93 \\
\hline 2 & Penggunaan komputer dalam proses pembelajaran & 4,59 & 3,67 & 0,92 \\
\hline 3 & Ketersediaan komputer untuk keperluan akademik peserta didik & 4,61 & 3,71 & 0,90 \\
\hline 4 & Ketersediaan komputer dalam memenuhi jumlah peserta didik & 4,60 & 3,72 & $\mathbf{0 , 8 8}$ \\
\hline 5 & Ketersediaan meja dan kursi di setiap ruang layanan & 4,59 & 3,72 & $\mathbf{0 , 8 7}$ \\
\hline 6 & Kenyamanan meja dan kursi di ruang layanan & 4,65 & 3,71 & 0,95 \\
\hline 7 & Kenyamanan ruang layanan & 4,64 & 3,68 & 0,96 \\
\hline 8 & Kesesuaian layanan dengan SOP & 4,60 & 3,68 & 0,92 \\
\hline 9 & Kesungguhan petugas mendengar keluhan peserta didik & 4,56 & 3,69 & 0,86 \\
\hline 10 & Kualitas udara di ruang layanan & 4,66 & 3,71 & 0,95 \\
\hline 11 & Kualitas penataan meja dan kursi di ruang layanan & 4,65 & 3,69 & 0,96 \\
\hline 12 & Tanggungjawab petugas terhadap layanan yang diberikan & 4,60 & 3,74 & $\mathbf{0 , 8 6}$ \\
\hline 13 & $\begin{array}{l}\text { Monitoring oleh petugas mengenai persoalan penggunaan komputer } \\
\text { yang dihadapi peserta didik }\end{array}$ & 4,65 & 3,71 & 0,94 \\
\hline 14 & $\begin{array}{l}\text { Kemampuan petugas dalam memberikan solusi terhadap } \\
\text { permasalahan yang dihadapi peserta didik }\end{array}$ & 4,61 & 3,67 & 0,93 \\
\hline 15 & Kesungguhan petugas dalam membantu peserta didik & 4,61 & 3,78 & $\mathbf{0 , 8 3}$ \\
\hline 16 & Ketersediaan tempat sampah di ruang layanan & 4,64 & 3,79 & 0,85 \\
\hline 17 & Ketersediaan tempat sampah di luar ruang layanan & 4,58 & 3,76 & $\mathbf{0 , 8 2}$ \\
\hline 18 & Tata krama petugas ketika memberikan layanan & 4,66 & 3,72 & 0,94 \\
\hline 19 & $\begin{array}{l}\text { Waktu luang yang disediakan petugas dalam memberikan layanan } \\
\text { peserta didik }\end{array}$ & 4,60 & 3,72 & $\mathbf{0 , 8 8}$ \\
\hline 20 & Ketersediaan akses layanan & 4,57 & 3,70 & $\mathbf{0 , 8 7}$ \\
\hline 21 & Petugas cek ricek ketika melaksanakan tugas & 4,66 & 3,72 & 0,94 \\
\hline 22 & Kelancaran sistem komputer & 4,70 & 3,57 & 1,13 \\
\hline 23 & Kelengkapan software aplikasi & 4,64 & 3,42 & 1,22 \\
\hline 24 & Tata letak rak sepatu & 4,68 & 3,78 & 0,90 \\
\hline 25 & Tata letak fasilitas di ruang pendukung & 4,61 & 3,72 & $\mathbf{0 , 8 9}$ \\
\hline 26 & Kesiapan petugas sewaktu-waktu dalam melayani peserta didik & 4,69 & 3,75 & 0,94 \\
\hline 27 & Jaminan kualitas layanan yang diberikan & 4,63 & 3,68 & 0,94 \\
\hline 28 & Akurasi pelayanan yang diberikan petugas & 4,62 & 3,71 & 0,91 \\
\hline 29 & Kemampuan petugas menyelesaikan masalah peserta didik & 4,65 & 3,70 & 0,96 \\
\hline 30 & Pemahaman petugas terhadap permasalahan peserta didik & 4,59 & 3,74 & 0,86 \\
\hline 31 & Kesopanan petugas saat berkomunikasi terhadap peserta didik & 4,63 & 3,72 & 0,91 \\
\hline 32 & Keramahan petugas dalam bertutur kata & 4,64 & 3,76 & 0,89 \\
\hline 33 & Perhatian petugas secara penuh & 4,65 & 3,74 & 0,91 \\
\hline 34 & Kemampuan petugas mengakhiri layanan & 4,67 & 3,66 & 1,01 \\
\hline 35 & $\begin{array}{l}\text { Penguasaan petugas terhadap permasalahan yang sering dihadapi } \\
\text { peserta didik }\end{array}$ & 4,59 & 3,79 & $\mathbf{0 , 8 0}$ \\
\hline \multirow[t]{2}{*}{36} & Wawasan petugas mengenai permasalahan peserta didik & 4,61 & 3,73 & $\mathbf{0 , 8 8}$ \\
\hline & & 4,63 & 3,71 & \\
\hline
\end{tabular}

Analisis pemetaan prioritas dilakukan kepada semua item. Dari hasil olah data menggunakan IBM SPSS Statistic 23 diperoleh gambaran penyebaran item di diagram kartesius. 


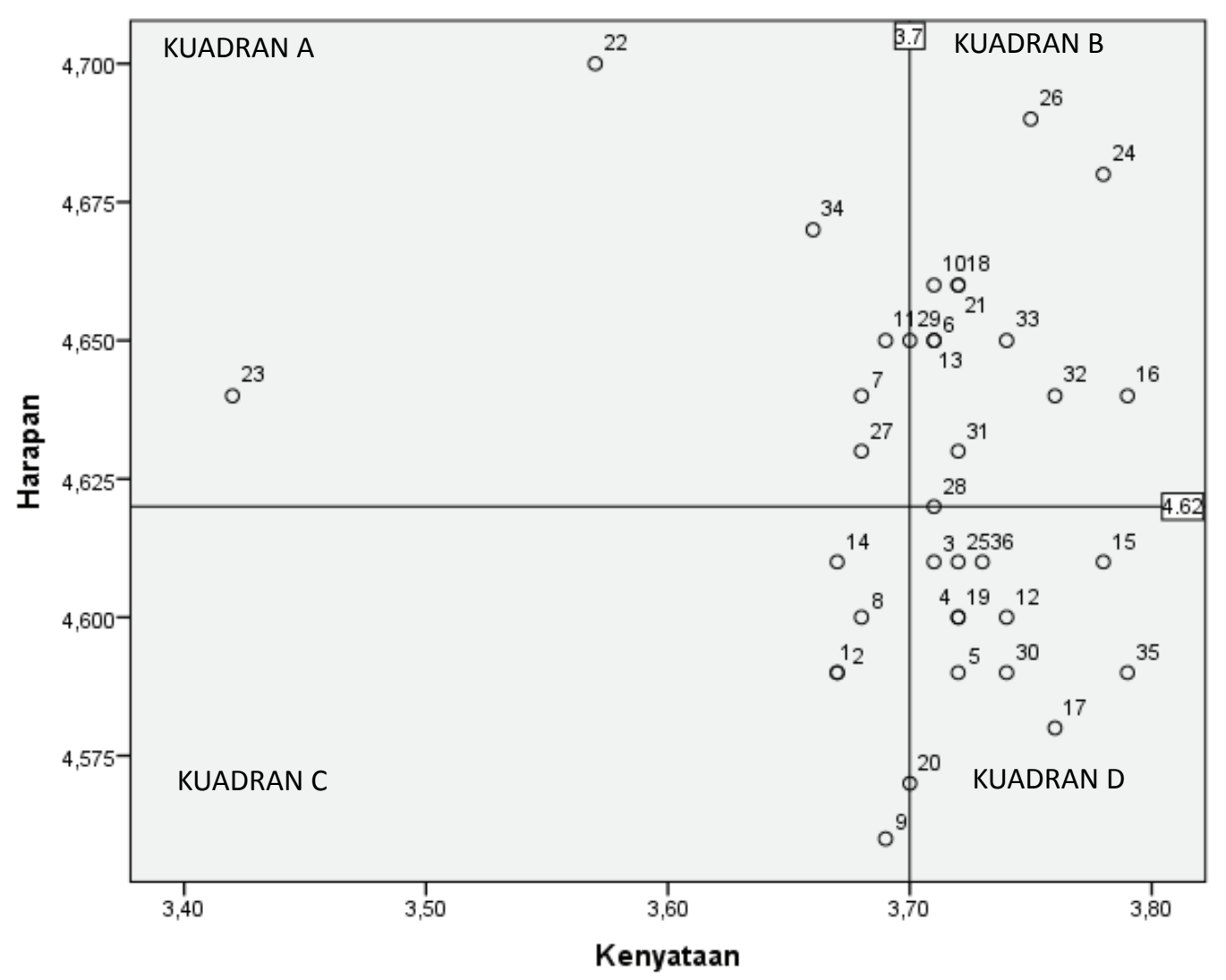

Gambar 1. Diagram Kartesius Layanan Evaluasi Hasil Belajar Online

Berdasarkan gambar diatas dapat diuraikan item Layanan Evaluasi Hasil Belajar Online yang termasuk ke dalam kuadran-kuadran sebagai berikut.

1. Kuadran A diketahui terdapat tujuh item yaitu kenyamanan ruang layanan, kualitas penataan meja dan kursi di ruang layanan, kelancaran sistem komputer, kelengkapan software aplikasi, jaminan kualitas layanan yang diberikan, kemampuan petugas menyelesaikan masalah peserta didik.

2. Kuadran B diketahui terdapat dua belas item yaitu kenyamanan meja dan kursi di ruang layanan, kualitas udara di ruang layanan, monitoring oleh petugas mengenai persoalan penggunaan komputer yang dihadapi peserta didik, ketersediaan tempat sampah di ruang layanan, tata krama petugas ketika memberikan layanan, petugas cek ricek ketika melaksanakan tugas, tata letak rak sepatu, kesiapan petugas sewaktu-waktu dalam melayani peserta didik, kesopanan petugas saat berkomunikasi terhadap peserta didik, keramahan petugas dalam bertutur kata, perhatian petugas secara penuh, akurasi pelayanan yang diberikan petugas.

3. Kuadran $\mathrm{C}$ diketahui terdapat enam item yaitu penggunaan komputer saat evaluasi hasil belajar, penggunaan komputer dalam proses pembelajaran, kesesuaian layanan dengan sop, kesungguhan petugas mendengar keluhan peserta didik, kemampuan petugas dalam memberikan solusi terhadap permasalahan yang dihadapi peserta didik, ketersediaan akses layanan.

4. Kuadran D diketahui terdapat sebelas item yaitu ketersediaan komputer untuk keperluan akademik peserta didik, ketersediaan komputer dalam memenuhi jumlah peserta didik, ketersediaan meja dan kursi di setiap ruang layanan, tanggungjawab petugas terhadap layanan yang diberikan, kesungguhan petugas dalam membantu peserta didik, ketersediaan tempat sampah di luar ruang layanan, waktu luang yang disediakan petugas dalam memberikan layanan peserta didik, tata letak fasilitas di ruang pendukung, pemahaman petugas terhadap permasalahan peserta didik, penguasaan petugas terhadap permasalahan yang sering dihadapi peserta didik, wawasan petugas mengenai permasalahan peserta didik. 


\section{PEMBAHASAN}

\section{Tingkat Ekspektasi Peserta Didik tentang Layanan Evaluasi Hasil Belajar Online}

Berdasarkan angket penelitian yang telah diisi oleh 272 responden tentang Tingkat Ekspektasi Peserta Didik terhadap Layanan Evaluasi Hasil Belajar Online memperoleh hasil bahwa tingkat ekspektasi peserta didik berada pada kategori cukup baik.

Kotler (dalam Sari, 2013) harapan pelanggan adalah "bagaimana pelanggan tersebut membentuk ekspektasi jasa dari banyak sumber, seperti pengalaman masa lalu, berita dari mulut ke mulut, dan iklan". Sejalan dengan itu, harapan pelanggan menurut Olson \& Oliver (dalam Tjiptono, 2016) adalah kepercayaan pelanggan sebelum mencoba sebuah produk yang dijadikan standar dalam menilai kinerja dari produk tersebut". Bagian yang paling penting dari layanan yang diberikan adalah kualitas dari layanan tersebut yang memiliki berbagai harapan dari pelanggan yang berbeda. harapan pelanggan merupakan hal yang dianggap mempunyai peranan besar yang dijadikan acun dalam menentukan kualitas layanan dan kepuasan dari pelanggan tersebut. Ketika pelanggan memperoleh layanan sesuai dengan apa yang diharapkan, maka pelanggan akan memberikan penilaian yang tinggi terhadap kualitas layanan yang diberikan, sebaliknya apabila layanan yang diperoleh tidak sesuai dengan apa yang diharapkan, maka pelanggan akan memberikan penilaian yang rendah terhadap kualitas layanan yang diberikan

Acuan ini dapat dilihat pada saat pelanggan memperoleh layanan tersebut. Kotler dan Keller (2008) mengemukakan bahwa terdapat beberapa faktor yang mempengaruhi harapan pelanggan diantaranya adalah: (1) Keluhan pelanggan adalah mencatat keluhan pelanggan dan menyelesaikan masalah pelanggan dengan cepat; (2) Kualitas produk dan jasa adalah totalitas fitur dan karakteristik produk dan jasa yang bergantung pada kemampuannya untuk memuaskan kebutuhan yang dinyatakan atau tersirat;(3) Pengaruh kualitas adalah kualitas produk dan jasa, kepuasan pelanggan dan profitabilitas perusahaan.

Pada penelitian ini, harapan pelanggan masuk dalam kategori cukup baik, tetapi sekolah sebagi tempat penyedia layanan harus tetap meningkatkan kualitas layanan yang diberikan dengan melihat dari faktor yang ada, seperti keluhan pelanggan yang harus diterima dan diperbaiki agar menjadi lebih baik lagi, meningkatkan kualitas dari layanan tersebut, pengaruh dari kualitas layanan sangat tinggi terhadap harapan dari pelanggan

\section{Tingkat Kenyataan menurut Persepsi Peserta Didik tentang Layanan Evaluasi Hasil Belajar Online}

Berdasarkan angket penelitian yang telah diisi oleh 272 responden tentang Tingkat Kenyataan menurut Persepsi Peserta Didik tentang Layanan Evaluasi Hasil Belajar Online memperoleh hasil bahwa tingkat persepsi terhadap Layanan Evaluasi Hasil Belajar Online di SMK Negeri 3 Malang dalam kategori cukup baik yang perbandingannya sama dengan tingkat ekspektasi terhadap Layanan Evaluasi Hasil Belajar Online di SMK Negeri 3 Malang dalam kategori cukup baik. Harapan dari peserta didik cukup baik atas layanan yang diberikan oleh SMK Negeri 3 Malang, tetapi kedepannya tetap harus diperbaiki dan ditingkatkan kembali agar layanan yang diterima oleh peserta didik dalam kategori sangat baik atau sangat memuaskan. Hasil penelitian ini sesuai dengan penelitian yang dilakukan oleh Merdekasari (2016) yang menyatakan tingkat kepuasan siswa pengguna layanan angkutan berada dalam kategori cukup.

Kepuasan merupakan perasaan senang atau tidak senang seseorang yang muncul setelah mendapatkan produk atau pelayanan jasa yang sesuai dengan harapan mereka. Zulkarnain \& Sumarsono (2018) kepuasan merupakan tingkat perasaan seseorang setelah membandingkan kinerja hasil layanan yang dirasakan dengan yang diharapkan. Kepuasan merupakan perasaan senang atau tidak senang seseorang yang muncul setelah mendapatkan produk atau pelayanan jasa yang sesuai dengan harapan mereka. Pada penelitian ini tingkat persepsi peserta didik masuk dalam kategori cukup puas tetapi masih dalam batas minimal, walaupun harapan dari peserta didik juga dalam kategori cukup puas. Tetapi tidak menutup kemungkinan harus diadakan perbaikan layanan agar layanan yang diterima peserta didik semakin baik. 


\section{Perbedaan Antara Ekspektasi dan Persepsi Peserta Didik tentang Layanan Evaluasi Hasil Belajar Online}

Kepuasan peserta didik pada dasarnya bergantung pada persepsi dan harapan mereka terhadap penyedia jasa layanan yang dalam hal ini adalah sekolah sebagai tempat penyedia kebutuhan pendidikan. kepuasan pelanggan atau pengguna jasa sangat perlu untuk diperhatikan karena suatu kepuasan akan mempengaruhi minat pengguna dalam menggunakan jasa yang di tawarkan (Prasetyo, 2016).

Kualitas layanan dapat mempengaruhi peserta didik dalam menggunakan sebuah produk atau jasa yang diberikan, sehingga kualitas layanan harus mampu dikelola dengan baik. Kualitas layanan adalah derajat pemenuhan kebutuhan dan keinginan peserta didik maupun orangtua peserta didik serta ketepatan penyampaiannya untuk mengimbangi atau melebihi harapan mereka yang diketahui melalui penilaian responden (Sari, 2013). Kualitas pelayanan ukurannya bukan hanya ditentukan oleh pihak yang melayani saja tetapi lebih tetapi lebih banyak oleh pihak yang dilayani, karena merekalah yang menikmati layanan sehingga dapat mengukur kualitas pelayanan berdasarkan harapan-harapan mereka dalam memenuhi kepuasannya (Prasetyo, 2016).

Hasil penelitian menunjukkan bahwa tidak ada perbedaan yang signifikan antara tingkat ekspektasi dan persepsi peserta didik tentang Layanan Evaluasi Hasil Belajar Online di SMK Negeri 3 Malang. Hal ini ditunjukkan dari hasil pengujian dengan menggunakan uji one way anova pada IBM SPSS statistic 23, berdasarkan deskriptif harapannya menunjukkan bahwa ada perbedaan ekspektasi dari setiap jurusan yang ada. Dengan nilai (Sig.) 0,557 > 0,05 yang dapat disimpulkan bahwa rata-rata harapan kelima jurusan tersebut "sama" secara signifikan. Sedangkan dilihat dari deskriptif kenyataannya pun sama memiliki perbedaan di masing-masing jurusan. Dengan nilai (Sig.) 0,558 $>0,05$ yang dapat disimpulkan bahwa rata-rata kenyataan kelima jurusan tersebut "sama" secara signifikan. Artinya bahwa terdapat perbedaan yang signifikan antara tingkat ekspektasi peserta didik dan tingkat persepsi peserta didik di SMK Negeri 3 Malang. Hal ini terbukti dari berbagai penelitian yang menunjukkan adanya perbedaan yang signifikan antara ekspektasi dan persepsi peserta didik terhadap kualitas layanan (Yulianti, 2016).

Listifadah (2011) menyatakan kualitas jasa dipengaruhi oleh dua faktor, yaitu jasa yang dirasakan (perceived service) dan jasa yang diharapkan (expected service). Jika terdapat ketidaksesuaian antara jasa yang dirasakan dengan jasa yang diharapkan akan timbul kesenjangan (gap). Untuk menghitung rata-rata tingkat kinerja dalam mempersepsi peserta didik dapat dilakukan dengan menggunakan analisis importance performance. Berdasarkan hasil penelitian gap analisis tingkat ekspetasi dan tingkat persepsi pada semua item menunjukkan hasil rata-rata gap dari tingkat ekspektasi ada 4,63 yang berarti bahwa peserta didik berharap tinggi pada layanan evaluasi belajar Online yang diberikan oleh sekolah. Dalam hal tingkat persepsi hasil rata-rata gap berada pada nilai 3,71 yang memiliki arti bahwa kinerja layanan sudah baik tetapi masih masuk dalam prioritas perbaikan. Untuk hasil rata-rata gap tingkat ekspektasi dan tingkat persepsi Layanan Evaluasi Hasil Belajar Online di SMK Negeri 3 Malang menunjukkan bahwa tingkat ekspektasi peserta didik terhadap layanan evaluasi hasil belajar Online lebih tinggi terhadap tingkat kinerja Layanan Evaluasi Hasil Belajar Online, dengan gap tertinggi ada pada 1,22 untuk Layanan Evaluasi Hasil Belajar Online. Pada kenyataannya semua item memiliki nilai gap yang berbeda, dapat diartikan bahwa tingkat kinerja Layanan Evaluasi Hasil Belajar Online di SMK Negeri 3 Malang menurut persepsi peserta didik dalam kategori cukup baik dengan tetap masuk dalam prioritas perbaikan. Karena rata-rata dari seluruh item Layanan Evaluasi Hasil Belajar Online di SMK Negeri 3 Malang menunjukkan hasil < 1 sesuai dengan teori Parasuraman (dalam Yulianti, 2016) bahwa perbaikan harus tetap diprioritaskan karena nilai kesenjangan yang menunjukan keseluruhan bernilai negatif, yang berarti masih ada item yang dirasa mahasiswa belum sesuai harapan.

Dalam penelitian ini juga dijelaskan melalui hasil uji analisis importance performance yang digambarkan melalui diagram kartesius. Diagram kartesius digunakan untuk menggambarkan posisi dari item tingkat kepentingan bagi peserta didik. hasil diagram kartesius pada kuadran A, terdapat tujuh item menjadi prioritas perbaikan utama yang harus dilaksanakan sesuai dengan harapan peserta didik, karena faktor tersebut dianggap sangat penting namun pada kinerjanya masih belum sesuai dengan ekspektasi peserta didik. Sekolah harus lebih memprioritaskan peningkatan kinerjanya pada atribut yang berada di kuadran A agar sesuai dengan ekspektasi peserta didik. 
Pada kuadran B menunjukkan keberadaan item layanan yang juga dianggap penting oleh peserta didik dan kinerjanya juga dianggap memuaskan oleh peserta didik. Sekolah dalam hal ini harus mempertahankan kinerja item ini agar dapat terus menjadi lebih baik dan dapat terus memenuhi apa yang di harapkan peserta didik. Dalam kuadran B menunjukkan ada dua belas item yang harus dipertahankan dan di tingkatkan lagi dalam hal kinerja layanan Evaluasi Hasil Belajar Online di SMK Negeri 3 Malang.

Pada kuadran $\mathrm{C}$ terdapat enam item yang tidak mempunyai harapan tinggi dari peserta didik tetapi pada kinerjanya juga masih biasa saja. Sekolah harus memberikan fokus perbaikan untuk item yang berada pada kuadran ini agar kedepannya tingkat ekspektasi peserta didik dapat naik dan juga kinerja yang dihasilkan lebih baik pula.

Pada kuadran D terdapat sebelas item yang sudah melampui ekspektasi dari peserta didik atas kinerja Layanan Evaluasi Hasil Belajar Online. Sekolah harus tetap mempertahankan kinerja dalam kuadran ini karena harapan peserta didik telah tinggi.

\section{SIMPULAN}

Tingkat ekspektasi peserta didik terhadap Layanan Evaluasi Hasil Belajar Online termasuk dalam kategori cukup baik. Tingkat persepsi peserta didik terhadap Layanan Evaluasi Hasil Belajar Online di SMK Negeri 3 Malang termasuk dalam kategori cukup baik.Tidak ada perbedaan yang signifikan antara tingkat ekspektasi peserta didik terhadap Layanan Evaluasi Hasil Belajar Online di SMK Negeri 3 Malang dengan tingkat persepsi peserta didik terhadap Layanan Evaluasi Hasil Belajar Online di SMK Negeri 3 Malang.

\section{DAFTAR RUJUKAN}

Ashary, F. A. D. 2018. Penerapan Media Evaluasi Berbasis Komputer (CBT) pada Mata Pelajaran Pengantar Akuntansi Keuangan terhadap Hasil Belajar Siswa di SMK Muhammadiyah 5 Kepanjen. Skripsi tidak diterbitkan. Malang: FE UM

Hasibuan, M. 2012. Manajemen Sumber Daya Manusia. Jakarta: PT Bumi Aksara.

Kotler, P., \& Keller, K.L. 2008. Marketing Management. (Terjemahan Oleh: Bob Sabran). Jakarta: Erlangga.

Liana, N.A. 2016. Analisis Faktor yang Mempengaruhi Kepuasan Orang Tua Peserta Didik terhadap Layanan Pendidikan. Manajemen Pendidikan Vol 25 1(2016), 39-46.

Listifadah, dkk. 2011. Analisis Kualitas Pelayanan dan Pengendalian Kualitas Jasa Berdasarkan Persepsi Pengunjung. Media Statistika, 1(2011), 33-45.

Merdekasari, A. D. 2016. Hubungan Kualitas Layanan Angkutan Kota dan Kepuasan dalam Pengangkutan Siswa di Kota Malang. Skripsi tidak diterbitkan. Malang: FIP UM.

Prasetyo, D. W. 2016. Tingkat Kepuasan Siswa dalam Menggunakan Jasa Pelayanan Perpustakaan Sekolah di MAN Ypgyakarta III. Skripsi Tidak Diterbitkan. Yogyakarta: FIP UNY.

Rahma, A., \& Hartoyo. 2010. Pengaruh Karakteristik Orang Tua dan Sekolah Terhadap Tingkat Kepuasan Pelayanan Pendidikan Dasar. Jurnal Ilmu Keluarga \& Konsumen. (Online). Vol. 3 No.2 ISSN: 1907-6037, (http://download. Portalgaruda.org/article.php?article=86088\&val=239) diakses 15 Januari 2020.

Rizki, N.H. 2017. Pengaruh Kualitas Layanan UPT Perpustakaan terhadap Kepuasan dan Intensitas Pemanfaatan Mahasiswa FIP Universitas Negeri Malang. Skripsi tidak diterbitkan. Malang: FIP UM.

Sallis, E. 2010. Manajemen Mutu Pendidikan. Yogyakarta: Diva Press.

Sari, R.P. 2013. Pengaruh Kualitas Pelayanan Sekolah Terhadap Kepuasan Peserta Didik dan Orang Tua Peserta Didik. Manajemen Pendidikan 2(2013), 146-156.

Setyadin, B. 2005. Modul IV: Desain dan Metode Penelitian Kuantitatif. Malang: Universitas Negeri Malang.

Sholikah, G.P. 2015. Tanggapan Siswa Kelas XII Jurusan Tata Busana tentang Pelaksanaan Ujian Online di SMK Negeri 5 Malang Tahun Pelajaran 2014/2015. Skripsi tidak diterbitkan. Malang: FT UM Tjiptonio, F \& Chandra, G. 2016. Service, Quality, dan Satisfaction. Yogyakarta: Andi Offset.

Tjiptonio, F \& Chandra, G. 2016. Service, Quality, dan Satisfaction Edisi 4. Yogyakarta: Andi Offset. Undang-Undang Nomor 20 Tahun 2003 tentang Sistem Pendidikan Nasional. 2013. Jakarta: Sinar Grafika.

Wijaya, T. 2011. Manajemen Kualitas Jasa. Jakarta: PT Indeks. 
Yulianti, Y. 2016. Analisis Kualitas Pelayanan Pendidikan dengan Menggunakan Gap Analysis dan Importance Performance Analysis (IPA) Pada Program Studi Pendidikan Ekonomi Fakultas Ekonomi UNY. (Online). (http://eprints.uny.ac.id/46247/1/SKRIPSIFULL_YAYU\%20YULIANTI_11404241011.pd) diakses 1 Juli 2019. 